\title{
COMPARATIVE EFFICACY OF SOME BOTANICAL EXTRACTS AND COMMERCIAL COATING MATERIALS FOR IMPROVING THE STORAGE LIFE AND MAINTAIN QUALITY OF KINNOW MANDARIN (CITRUS RETICULATA L.)
}

\author{
RASHID, M. Z..$^{1 *}$ AHMAD, S. ${ }^{1}-$ KHAN, A. $.{ }^{1}{ }^{1}-$ ALI, B. ${ }^{2}$ \\ ${ }^{I}$ Institute of Horticultural Sciences, University of Agriculture, Faisalabad, Pakistan \\ ${ }^{2}$ Department of Agronomy, University of Agriculture, Faisalabad, Pakistan \\ *Corresponding author \\ e-mail:vafzahid@gmail.com
}

(Received $16^{\text {th }}$ Jun 2019; accepted $16^{\text {th }}$ Oct 2019)

\begin{abstract}
Citrus is one of the most promising fruit crops of Pakistan owing to its delicious taste and excellent aroma. Kinnow being a promising variety has a significant importance in the global market. Pakistan is facing a drastic reduction in Kinnow mandarin quality due to improper postharvest management and hence severe losses regarding quality and shelf life which might be up to $40 \%$. The aim of this study was to find some alternative botanical product against chemical (fomesa) wax and fungicide to extend the shelf life of Kinnow mandarin. Fruits were treated with fomesa wax, 30\% coconut oil, $60 \%$ aloe vera extract and Thiabendazole (TBZ) with standardized doses and stored at $5^{\circ} \mathrm{C}$ for 90 days. It was observed that $30 \%$ coconut oil performed almost at par to commercial wax and better than all other treatments. The fruits treated with $30 \%$ coconut oil showed minimum weight loss $(11.70 \%)$, fruit rot $(5.83 \%)$, maximum juice weight $(42 \mathrm{~g})$, biochemical parameters such as total soluble solids $\left(10.90^{\circ} \mathrm{Brix}\right)$,

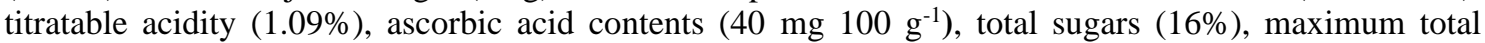
antioxidants (70\% inhibition) and maximum enzymatic activity [catalase (18.10 $\mathrm{U} \mathrm{mg}^{-1}$ protein), peroxidase $\left(0.79 \mathrm{U} \mathrm{mg}^{-1}\right.$ protein) and superoxide dismutase (133.93 $\mathrm{U} \mathrm{mg}^{-1}$ protein)] of Kinnow fruits which were stored up to 90 days. It was concluded from the present study that pre storage treatment of $30 \%$ coconut oil was the most effective to reduce decay losses and maintain the fruit quality during 90 days storage.
\end{abstract}

Keywords: wax \& fungicide, postharvest losses, coconut oil

\section{Introduction}

Citrus is ranked first among fruit crops, consisting almost $40 \%$ of fruits being grown in Pakistan, and enlists the country amongst top 15 producers of the world. The Kinnow is the extensively cultivated variety of citrus fruit and a common name of mandarin (Citrus reticulate L.) in Pakistan. The Kinnow grown in this region is a result of cross between King Citrus nobilis and Citrus deliciosa of Riverside California and is the principal citrus commercial cultivar. In Pakistan, Kinnow mandarin occupies imperative position among fruits (Siddique and Garnevska, 2018). In Pakistan, Kinnow export increased tremendously 2017-18 and touched a record of 370,000 tons compared to the previous year (Trade Development Authority of Pakistan, 2018).

Main Kinnow growing areas of Pakistan are Sargodha, Faisalabad, Bhalwal, Toba Tek Singh, Mandi Bahauddin and Sahiwal. Sargodha share 95\% from total production of citrus in country (GOP, 2015). Kinnow is a good source of vitamin C, carbohydrates (fructose, glucose and sucrose), also having significant magnesium and calcium quantity. Similarly, Citrus fruits also have significant amount of 
phytochemicals (monoterpenes, limonoids and flavonoids, carotenoids) which help to reduce the chance of cardiovascular diseases, cancer and cataracts (Arowora et al., 2013; Singh et al., 2018).

In Pakistan, Kinnow export increased tremendously 2017-18 and touched a record of 370,000 tons compared to the previous year (Trade Development Authority of Pakistan, 2018).

Postharvest losses ranges from $23-38 \%$ and sometimes up to $40 \%$ while $5-10 \%$ in developed countries containing Brazil, Australia, Spain, USA, Israel and Italy (FAOSTAT, 2017). These losses caused due to absence of suitable pre and postharvest management practices, restricted cold chain services, inadequate packing houses and usually sluggish marketing system consequently low return to processor, farmer and trader (FAO, 2006). Kinnow need the proper management system to retain its good quality because there is a risk of deterioration of Kinnow after its harvesting in case of inappropriate management.

Among the various approaches applied to enhance the shelf life substitute of efficient cost technology, utilization of edible coating (wax, oil, extracts) to fruit has attained a considerable attention worldwide in these days (Tietel et al., 2010). For the formulation of comestible films and coatings, different kinds of materials are practiced having very indispensable features (Sindhu and Singhrot, 2016).

Effects of different treatments including commercial wax, herbal extracts (Fan et al., 2009; Romanazzi, 2010) essential oils, edible oils, Chitosan (Xu et al., 2007; Obenland et al., 2008; Paolo and Marisol, 2008) and fungicide has been studied to sustain quality of the fruit covering and increase shelf-life of citrus (Kinnow) fruits. Bisen et al. (2008) illustrated that increased kagzi lime's firmness and decreased fruit weight losses could be ensured with the optimum application of mustard oil. Though, short studies have been done regarding use of different edible oil base coatings to increase the storage life of the Kinnow fruit. In recent times, aloe vera gel based edible coating trend has been increasing for the preservation of different fruits and vegetables (Valverde et al., 2005; Chauhan et al., 2014; Hassanpour, 2015). This tasteless natural product eco-friendly substitute to artificial preservative and delays, respiration rate and reduce proliferation of microorganisms in fruits (Castillo et al., 2010; Garcia et al., 2013; Sogvar et al., 2016). Application of coconut oil, castor oil and sesame oil as postharvest covering of fruits cause reduction in moisture and weight loss of fruits (Creel et al., 2006; Ali et al., 2010).

A number of plants have recognized and classified by Grainge et al. (1984) which possess fungicidal and growth regulating properties, as well as some plants such as neem, lantana and melia. Moreover, neem leaves, fruits and bark have enormous pharmacological properties like anti-ulcer, anti-fungal, anti-bacterial, and pesticide (Biswas et al., 2002).

Aloe vera is a natural product having no taste which is safe and also environment friendly as the alternate for the synthetic preservative. It is used in numerous cases as prevention tool to manage fruit decay as its gel based edible coatings used to avert the respiration rate, delay oxidative browning, moisture loss and firmness. Owing to presence of numerous complex ingredients (enzymes, amino acid, phenolic compounds, salicylic acid, and glycoproteins) it is considered as a beneficial plant (Serrano et al., 2006). These ingredients possess the antifungal properties (Nidiry et al., 2011). Hence Aloe vera reduces the proliferation of various insects, pests and microorganisms in fruits (Castillo et al., 2010). 
In Pakistan the use of fungicide is very common to control postharvest diseases but unfortunately, the application of non-chemical techniques is being ignored which can prevent the harmful consequences for human health. The use of chemicals has been discouraged to control the losses of fruits worldwide as there is emergence of concepts regarding food safety in the postharvest supply chain. The import of food commodities with chemical residues has been banned by numerous countries (Khalid et al., 2012).

The National standards fixed maximum residual limit (MRL) on fruits' exports which exceeds this limit would be rejected by importers (Pesticide Action Network, 2012). Industry is facing the challenge to maintain the quality of fruit with minimum chemical residues. The plant extract and organic nature mineral oil is the best alternate to control the pre and postharvest disease for the fruits across the world.

Commercial waxes are usually expensive which are being used in food industry so, there is need to introduce low-cost and effective eco-friendly bio product like oil and plant extracts which are edible and have no residual effect on human health. In view of contemporary scenario high priced wax, fungicide and to reduce postharvest losses, this current investigation was planned with this objective to ascertain the best local plant extract and oil to sustain the quality and storage life of Kinnow fruits.

\section{Materials and methods}

The current study was planned to assess the effectiveness of different coatings like oil, plant extracts, commercial wax and fungicide to increase the consumption period of Kinnow and all the experimentations were carried out at Postgraduate Pomology Laboratory (PPL) in University of Agriculture Faisalabad (UAF) Pakistan during 20152016. Physiologically matured Kinnow fruits were picked from Experimental Fruit Orchard, located in UAF. The fruits were brought to PPL and were graded to get rid of unhealthy or bruised ones. The fruits were cleaned up in tap water and dried under fan. All treatments (coating materials and storage day intervals) were evaluated under factorial CRD (Completely randomized design).

Plant extracts, oil were compared with commercial wax and fungicide. $\mathrm{T}_{0}$ : Control $\mathrm{T}_{1}$ : Fomesa wax, $\mathrm{T}_{2}: 30 \%$ Coconut oil, $\mathrm{T}_{3}: 60 \%$ Aloe vera extract (Best dose) and T4: Thiabendazole (TBZ) Commercial Fungicide. 20 fruits of Kinnow were used and each treatment was replicated four time. These plant extract were simply treated by dipping method. Treated Kinnow fruits were placed in cold storage at $5^{\circ} \mathrm{C}$ and $85 \% \mathrm{RH}$ for the time period of 90 days and quality parameters were studied up to 3 months (by keeping equal intervals of 15 days).

\section{Physical and physiological characteristics}

Fruits samples were weighed before storage and consecutive intervals of 15 days until the end of whole storage. The fruit parameters were calculated by using following formulas.

$$
\begin{gathered}
\text { Fruit rot }(\%)=\frac{\text { Spoiled fruits } x 100}{\text { Total fruits }} \\
\text { Weight loss }(\%)=\frac{\text { Initial weight of fruit-final weight of fruit } \times 100}{\text { Initial weight of fruit }}
\end{gathered}
$$


Peel weight $(g)$

The peel weight was measured using digital weight balance after peeling off fruit.

Peel weight was denoted as in $\mathrm{g}$.

$$
\text { Juice contents }(\%)=\frac{\text { Average juice weight } x 100}{\text { Average fruit weight }}
$$

\section{Physiochemical characteristics}

Total soluble solids $\left({ }^{\circ}\right.$ Brix $)$

Total Soluble solid was measured by a digital device named refractometer (RX 5000, Atago, Japan).

Titratable acidity (\%)

$$
T A(\%)=\frac{0.1 \mathrm{~N} \mathrm{NaOH} \times 0.0064 \times 100 \mathrm{ml} \text { juice used }}{\text { ml juice used }}
$$

\section{Ascorbic acid}

Juice contents regarding ascorbic acid were found following the procedure as described by AOAC (2000). A known quantity of juice $(10 \mathrm{ml})$ was poured into $100 \mathrm{ml}$ volumetric flask and final volume was prepared by adding $0.4 \%$ oxalic acid solution. $5 \mathrm{ml}$ filtrated aliquot was taken from the volume, and titrated against 2, 6dicholorophenolindophenol until the end point (light pink color).

$$
\text { Ascorbic acid }\left(m g 100 g^{-1}\right)=\frac{1 \times R 1 \times V \times 100}{R \times W \times V 1}
$$

\section{Total phenolic and total antioxidants}

The results regarding total Phenolic (mg GAE $100 \mathrm{~g}^{-1}$ ) were recorded using spectrophotometer at wavelength of $765 \mathrm{~nm}$ and $517 \mathrm{~nm}$, respectively (Ainsworth and Gillespie, 2007).

\section{Enzymes assay}

Frozen juice was used to estimate the enzymatic activities of POD, CAT an SOD after homogenization using phosphate buffer. The enzyme extracts were prepared and readings were recorded at spectrophotometer at specific wavelengths. The activity of enzyme was demonstrated as $\mathbf{U} \mathbf{~ m g}^{-1}$ protein (Liu et al., 2011).

\section{Statistical analysis}

The recorded data were subjected to statistical analysis of variance using two way ANOVA to examine the overall significant data, whereas the (LSD) least significant difference test $(P \leq 0.05)$ was performed for the comparison of means (treatments and storage periods) (Steel et al., 1997). 


\section{Results}

\section{Physical and physiological characteristics}

Weight loss (\%)

The weight of Kinnow fruit was gradually decreased during cold storage. The statistically evaluated data indicated significant results. The Kinnow fruits stored without any treatment indicated the highest weight loss than fomesa wax and $30 \%$ coconut oil treated fruits which showed 2.99 and 2.90-fold lower weight losses respectively. The interactive effects of different coatings and storage period showed higher weight loss $(31.80 \%)$ in control treatment followed by fruit treated with TBZ, $60 \%$ aloe vera extract, $30 \%$ coconut oil and fomesa wax where weight losses were $13.10 \%, 12.55 \%, 11.70 \%$, and $11.40 \%$, respectively. The interaction suggested that during 15-90 days interval control treatments had a continuous reduction in fruit weight, but treated fruits showed less decrease during first 60 days and during 75-90 days fast reduction occurred in fruit weight. Among all treatments Kinnow fruits treated with $30 \%$ coconut oil extract exhibited lower weight loss up to 90 days (Figure 1).

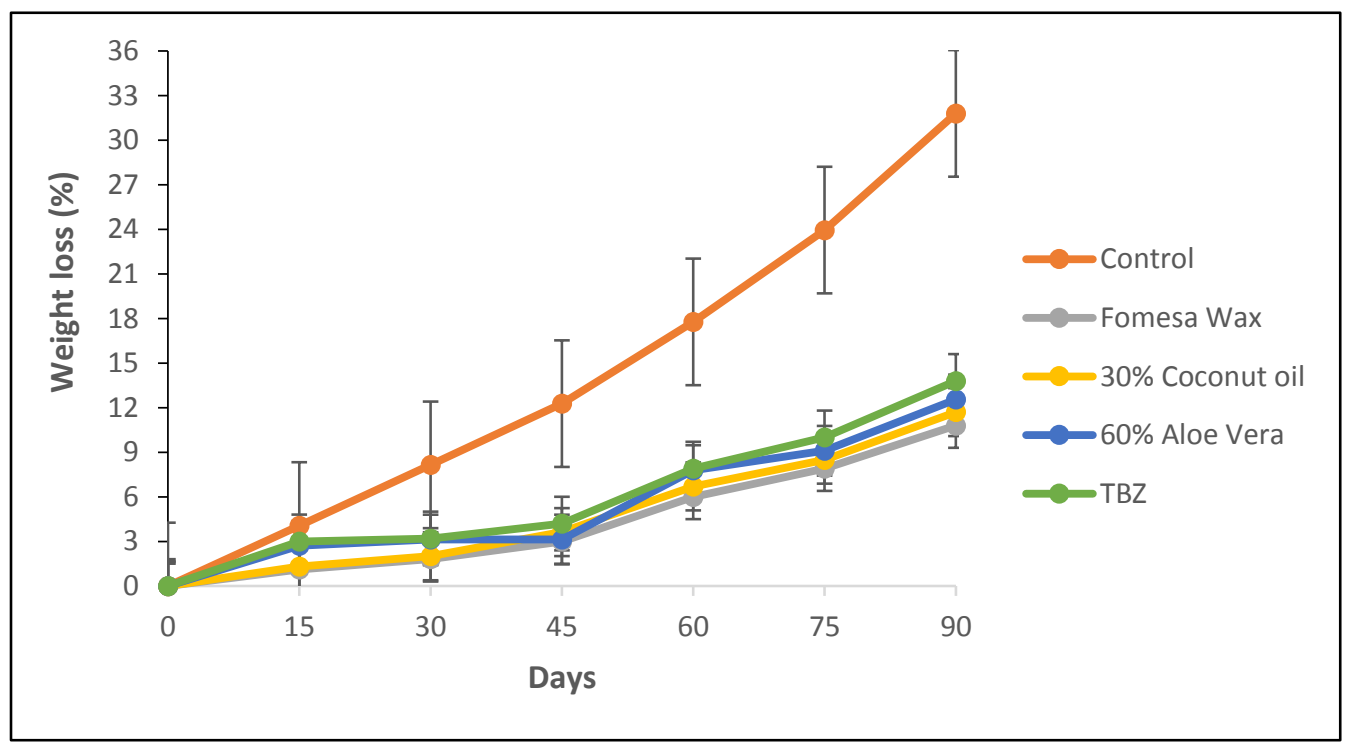

Figure 1. Effects of different coating treatments on weight loss (\%) of 'Kinnow' fruit stored at $5^{\circ} C$. LSD value $(p \leq 0.05)$ for treatments $=0.21$, storage days $=0.25$ and interaction $=0.56$

\section{Fruit rot (\%)}

Fruit rot of Kinnow mandarin fruit was progressively increased during storage period. The data depicted that Interactive effect of all treatments and storage days have significant impact on treatment means. The prestorage treatment of TBZ and $60 \%$ aloe vera showed lowest fruit rot $(0.93 \%$ and $1.16 \%)$ than untreated fruit respectively over 90 days storage period. The Kinnow treated with TBZ and 60\% aloe vera extract showed minor fruit rot which was statistically at par. The fruit rot was minimum $(0.79 \%)$ when Kinnow were examined after 15 days of storage where fruit rot percentage was the highest i.e. (9.09\%) when Kinnow were tested after 90 days. The interactive effects showed substantial results, the fruit rot $(29.20 \%)$ was maximum in control treatment when assessed after 90 days storage followed by fruit treated with 
$30 \%$ coconut oil and fomesa wax, where fruit rot were $5.83 \%, 5.23 \%, 2.83 \%$ and $2.35 \%$, respectively. Control treatments had swift increase in fruit rot (\%) after 45 days while TBZ and $60 \%$ aloe vera extract coating treatment which were at par showed minimum decay even during 75-90 days. It was interesting to analyze that TBZ and $60 \%$ aloe vera extract treated fruit showed almost $0 \%$ decay during initial 30 days while untreated fruits had $6.25 \%$ fruit rot during the same period (Figure 2).

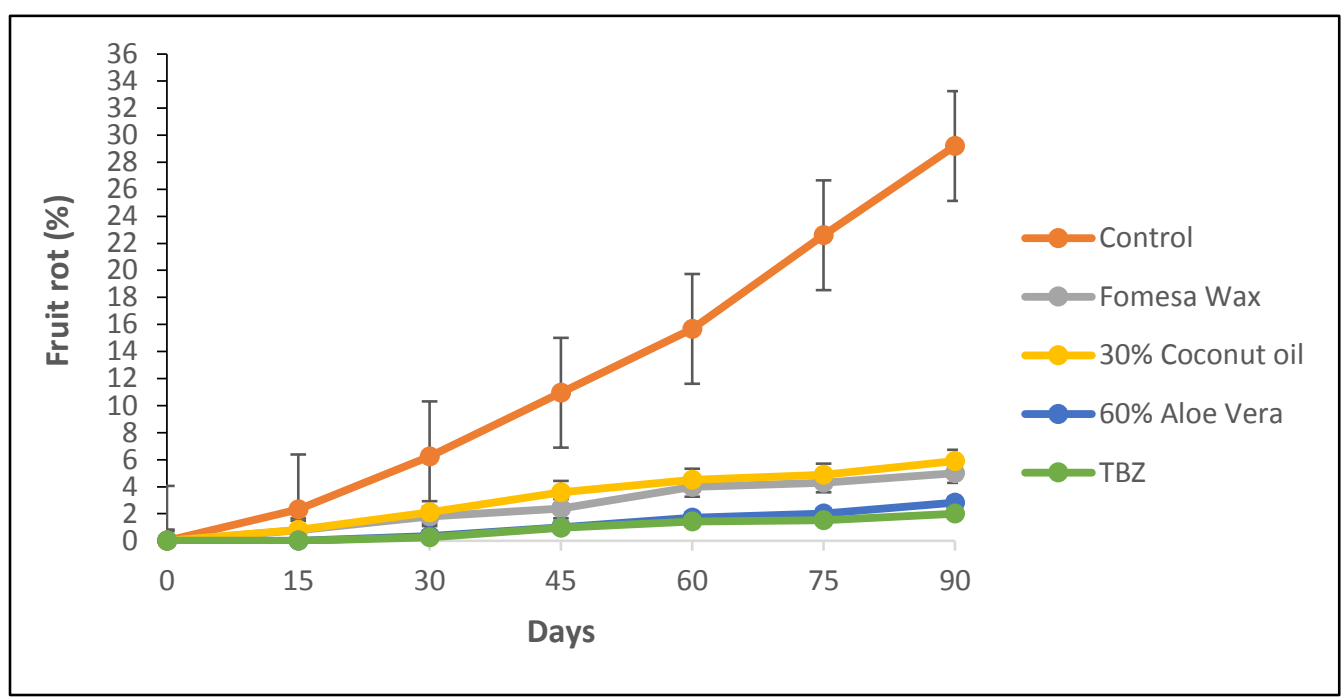

Figure 2. Effects of different coating treatments on fruit rot (\%) of 'Kinnow' fruit stored at $5^{\circ} \mathrm{C}$. LSD value $(p \leq 0.05)$ for treatments $=0.44$, storage days $=0.52$ and interaction $=1.17$

\section{Peel weight $(g)$}

Peel weight of Kinnow fruit was reduced due to loss of moisture, in this experimental study. The highest peel weight was maintained about 1.18 and 1.17 -fold by fomesa wax and $30 \%$ coconut oil treated fruit than control respectively during prolonge storage. The peel weights were 1.18, 1.32 and 1.53-fold higher over 45, 60 and 90 days storage period, respectively. A reverse relation in weight of peel and storage time was noted as the storage progressed. Kinnow fruits treated with fomesa wax held higher peel weight from 0-45 days while fomesa wax and $30 \%$ coconut oil showed parallel results to limit weight reduction from peel of fruits. (Figure 3).

\section{Juice contents (\%)}

It was noted that due to increased metabolic activities juice weight of Kinnow was steadily decreased in current study. The statistically investigated data depicted highly significant results among treatments, storage days and their interactions. Among different treatments Kinnow fruits treated with fomesa wax and $30 \%$ coconut oil revealed significantly 1.17 and 1.17-fold higher juice weight respectively after 90 days of cold storage. The application of coconut oil was effective to maintain the juice weight during storage period. A positive linear trend was observed for juice weight up to 0-45 days of storage when fruits were treated with $30 \%$ coconut oil and fomesa wax. However, an application 30\% coconut oil and fomesa wax proved to be at par with each other, similarly a sever negative linear trend was observed in untreated Kinnow fruits for peel weight when observed during 15-90 days. The interactive effects showed highly 


$$
-719 \text { - }
$$

significant results, during storage period of 30, 45, 60 and 90 days, juice weights were $1.09,1.15,1.22$ and 1.51-fold higher in fruits treated with $30 \%$ coconut oil than control fruit respectively (Figure 4).

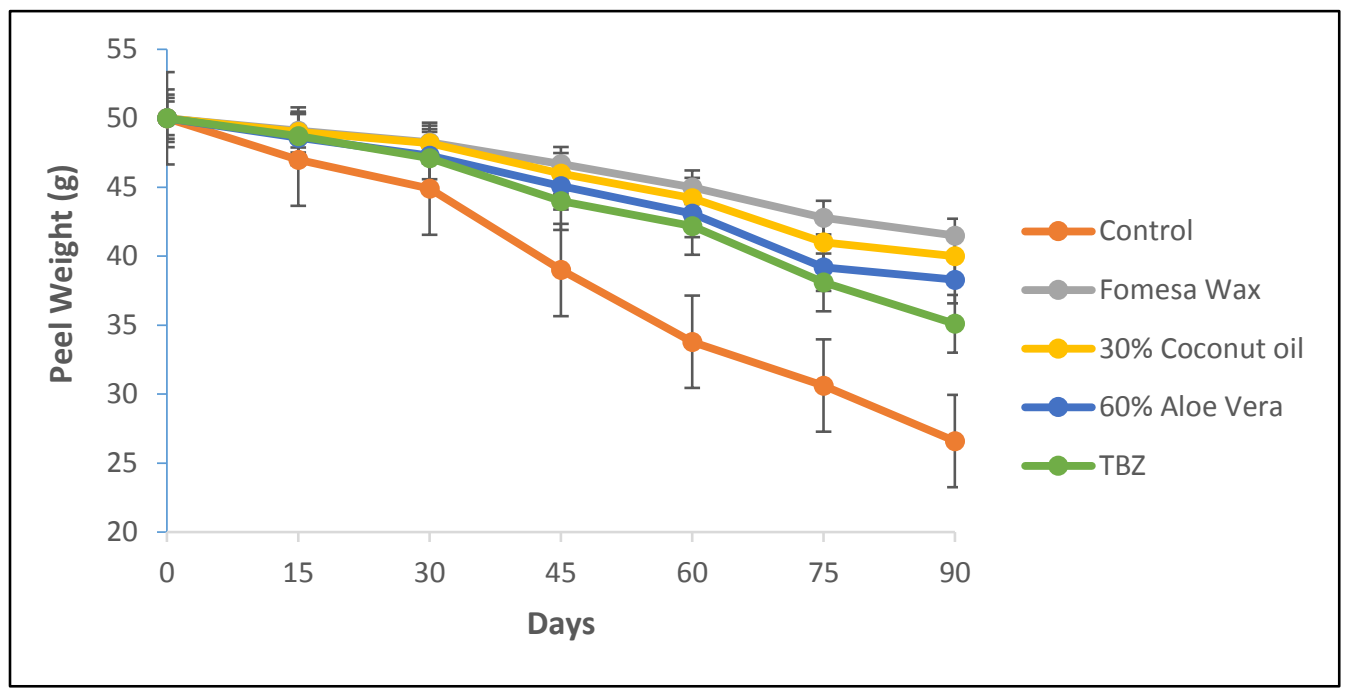

Figure 3. Effects of different coating treatments on peel weight ( $g$ ) of 'Kinnow' fruit stored at $5^{\circ} C . L S D$ value $(p \leq 0.05)$ for treatments $=0.23$, storage days $=0.28$ and interaction $=0.62$

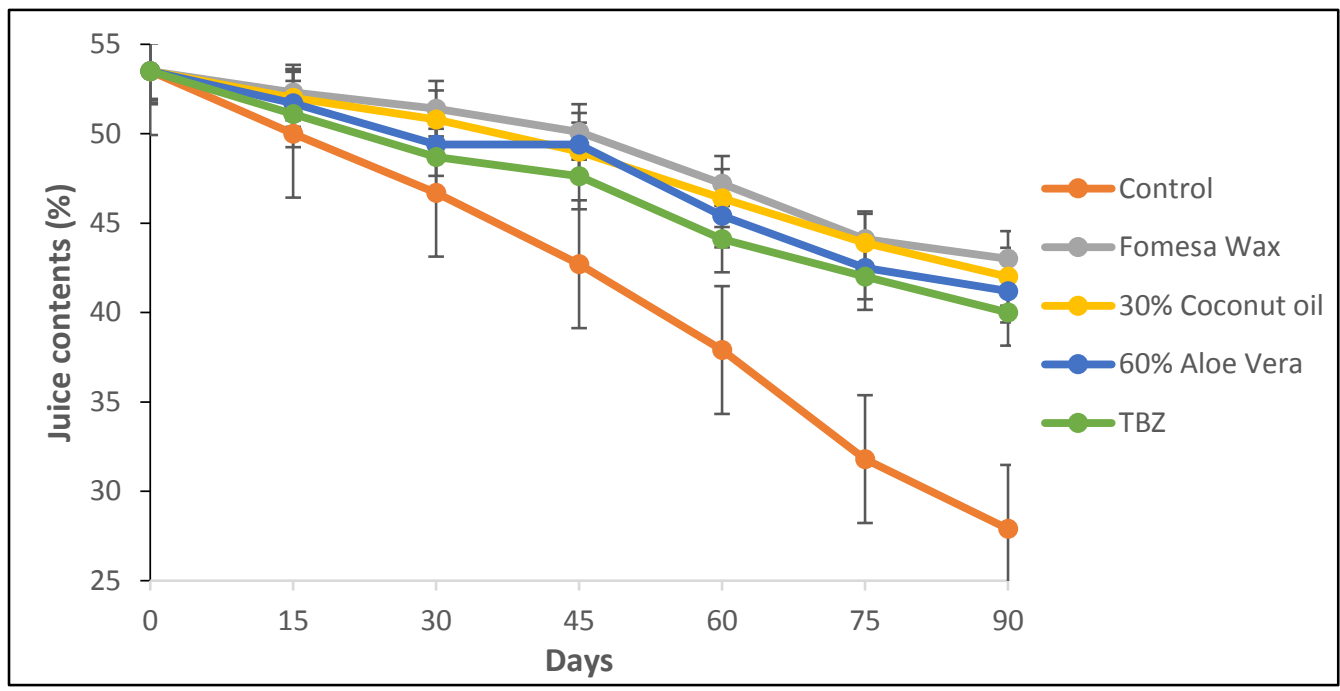

Figure 4. Effects of different coating treatments on juice contents (\%) of Kinnow mandarin stored at $5^{\circ} C . L S D$ value $(p \leq 0.05)$ for treatments $=0.27$, storage days $=0.32$ and interaction $=$

$$
0.73
$$

\section{Bio-chemical characteristics}

\section{Total soluble solids $\left({ }^{\circ}\right.$ Brix)}

The rapid increase in total soluble solid was found in control treatment than treated fruit. The Kinnow mandarin fruits treated with fomesa wax and $30 \%$ coconut oil exhibited the lower total soluble solid contents (1.12 and 1.11-fold) as matched to the untreated fruits respectively during whole storage time. The soluble solid contents were 
minimum $\left(9.25^{\circ}\right.$ Brix) when Kinnow were tested after 15 days of storage where soluble solid contents were highest i.e. $11.44^{\circ}$ Brix when Kinnow were analyzed after 90 days of storage. The results showed that coconut oil has positive impact on the TSS of fruits. No sever turn in total soluble solid was observed up to 45 days of storage, however, a blunt increase in TSS during 60-90 days was recorded. Furthermore, commercial wax performed at par to $30 \%$ coconut oil and helpful to maintain the soluble solid contents. After 30 and 90 days cold storage, total soluble solid contents were 1.06 and 1.11-fold in $30 \%$ coconut oil treated fruit than control respectively (Figure 5).

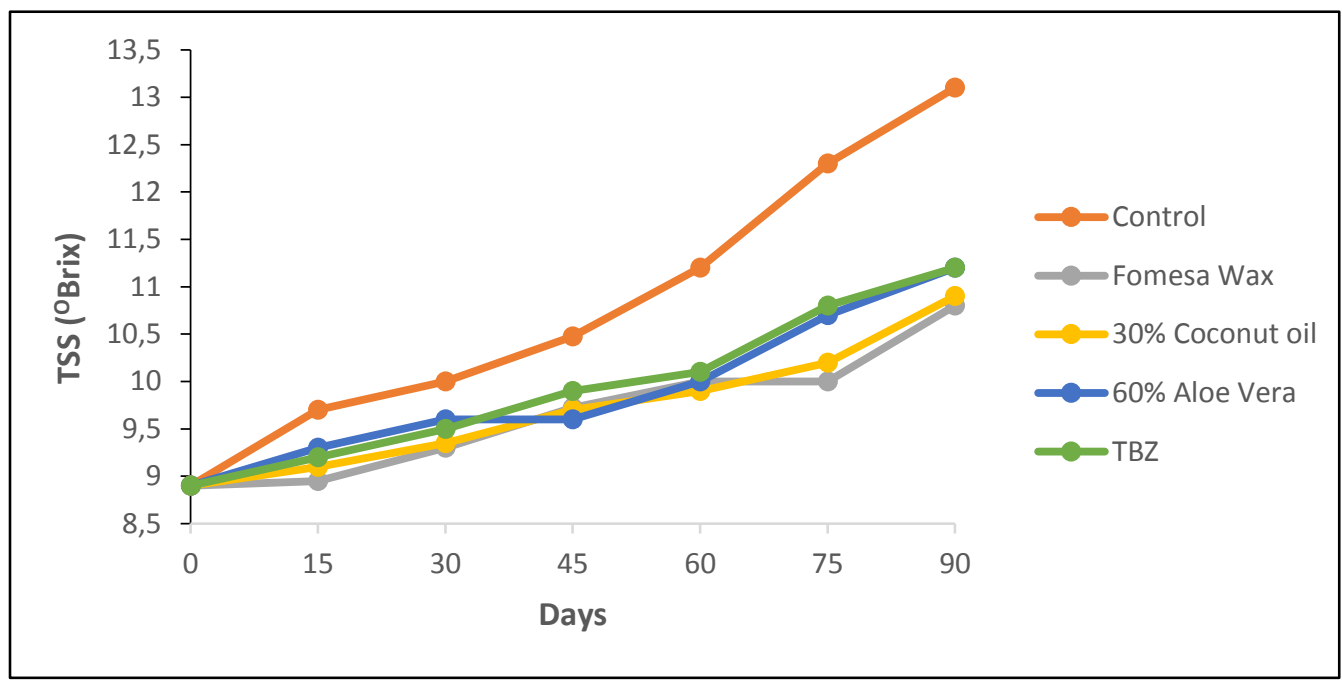

Figure 5. Effects of different coating treatments on TSS $\left({ }^{\circ}\right.$ Brix) of Kinnow fruit stored at $5^{\circ} \mathrm{C}$. $L S D$ value $(p \leq 0.05)$ for treatments $=0.17$, storage days $=0.20$ and interaction $=0.45$

\section{Titratable acidity (\%)}

Among the treatments, fomesa wax and $30 \%$ coconut oil treated fruit resulted in 1.21-fold higher titratable acidity than control during 90 days storage. Interactive effects exhibited that control treatments had an instant drop in TA after 45 days of storage, while, application of $30 \%$ coconut oil proved to be mandatory for sustaining the TA up to 60-90 days of storage. The interaction exhibited highest TA was observed in the treatments with fomesa wax (1.10) followed by the treatments of $30 \%$ coconut oil (1.09), 60\% aloe vera extract (1.01), TBZ (0.98) and control treatment (0.68) respectively after 90 days of storage. $30 \%$ coconut oil treated fruit exhibited higher $(1.17,1.24,1.32$ and 1.60-fold) titratable acidity in Kinnow fruits during storage (30, 45, 60 and 90 days) period respectively, than untreated fruit. It was found that titratable acidity of fruits was inversely proportional with prolong storage period (Figure 6).

\section{Vitamin $C\left(m g 100 \mathrm{~g}^{-1}\right)$}

The statistically investigated data showed highly significant results among treatments, storage days and their relation. The prestorage application of fomesa wax and 30\% coconut oil indicated around 1.22 and 1.21-fold higher ascorbic acid contents in Kinnow fruit than untreated fruit respectively. However, a gradual decreasing trend was noted after 15 days in control treatment while commercial wax and $30 \%$ coconut oil treated fruit had greater drop during 75-90 days. It was noted that highest vitamin $\mathrm{C}$ 
contents were observed in fruits treated with fomesa wax $\left(40.60 \mathrm{mg} 100 \mathrm{~g}^{-1}\right)$ followed

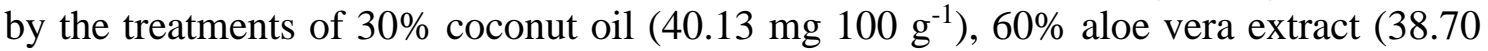
mg $\left.100 \mathrm{~g}^{-1}\right)$, TBZ (38.15 mg $\left.100 \mathrm{~g}^{-1}\right)$ and control treatment $\left(21.38 \mathrm{mg} 100 \mathrm{~g}^{-1}\right)$ after 90 days of respectively. During storage period of 30, 60 and 90 days $30 \%$ coconut oil treated fruit exhibited 1.02, 1.33 and 1.87-fold higher than control fruit respectively (Table 1).

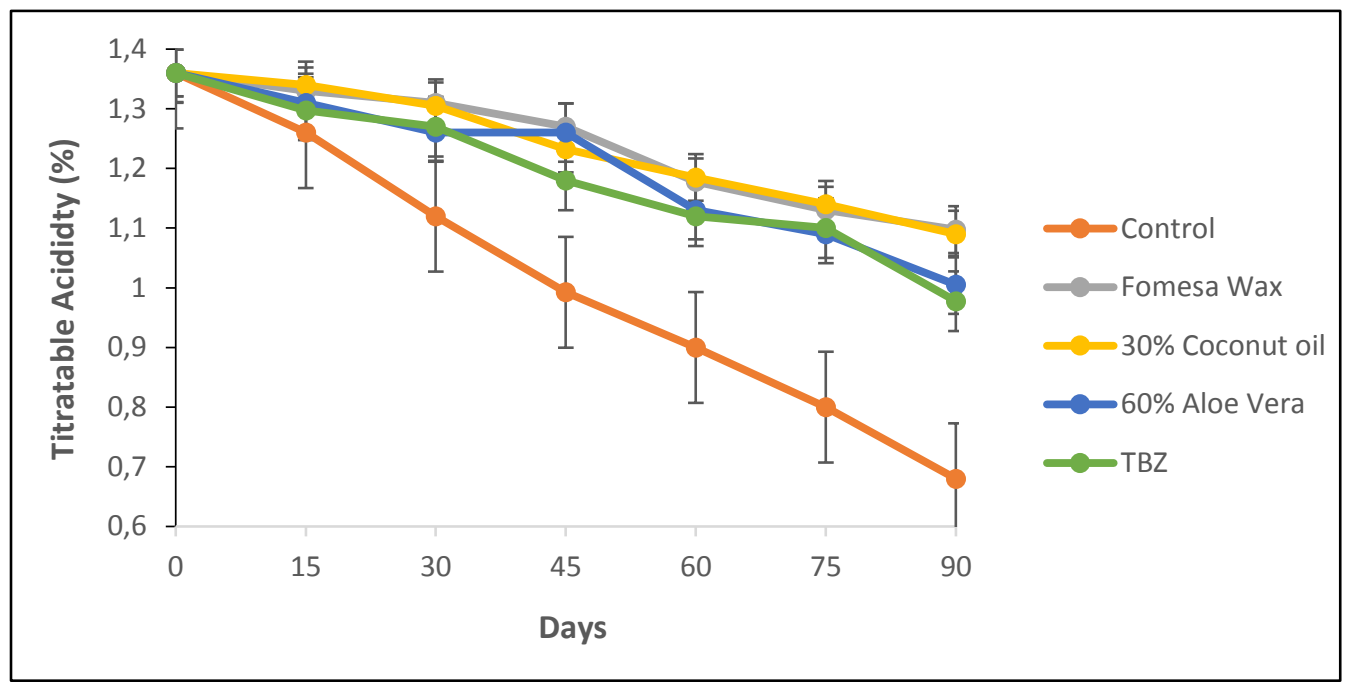

Figure 6. Effects of different coating treatments on titratable acidity (\%) of Kinnow fruit stored at $5^{\circ} C . L S D(p \leq 0.05)$ : treatments $=0.02$, storage days $=0.03$ and interaction $=0.06$

Table 1. Effects of different coating treatments on Vitamin $C\left(\mathrm{mg} 100 \mathrm{~g}^{-1}\right)$ of Kinnow fruit stored at $5^{\circ} \mathrm{C}$

\begin{tabular}{c|c|c|c|c|c|c|c|c}
\hline \multirow{2}{*}{ Treatments } & \multicolumn{7}{|c}{ Storage duration (days) } & \multicolumn{1}{c}{} \\
\cline { 2 - 8 } Control & $\mathbf{0}$ & $\mathbf{1 5}$ & $\mathbf{3 0}$ & $\mathbf{4 5}$ & $\mathbf{6 0}$ & $\mathbf{7 5}$ & $\mathbf{9 0}$ & Mean \\
\hline Fomesa Wax & $45.00 \mathrm{a}$ & $44.00 \mathrm{bc}$ & $42.83 \mathrm{ef}$ & $35.33 \mathrm{o}$ & $31.85 \mathrm{p}$ & $27.60 \mathrm{q}$ & $21.38 \mathrm{r}$ & $35.43 \mathrm{C}$ \\
$\mathbf{3 0 \%}$ Coconut oil & $45.00 \mathrm{a}$ & $44.83 \mathrm{ab}$ & $43.90 \mathrm{bcd}$ & $43.10 \mathrm{cdef}$ & $42.50 \mathrm{fg}$ & $41.13 \mathrm{hi}$ & $40.13 \mathrm{jkl}$ & $42.94 \mathrm{~A}$ \\
$\mathbf{6 0 \%}$ Aloe Vera & $45.00 \mathrm{a}$ & $44.53 \mathrm{ab}$ & $42.80 \mathrm{ef}$ & $41.70 \mathrm{gh}$ & $40.90 \mathrm{hij}$ & $39.83 \mathrm{kl}$ & $38.70 \mathrm{mn}$ & $41.92 \mathrm{~B}$ \\
TBZ & $45.00 \mathrm{a}$ & $44.60 \mathrm{ab}$ & $42.85 \mathrm{ef}$ & $41.58 \mathrm{gh}$ & $40.20 \mathrm{ijkl}$ & $39.60 \mathrm{~lm}$ & $38.15 \mathrm{n}$ & $41.71 \mathrm{~B}$ \\
\hline Mean & $\mathbf{4 5 . 0 A}$ & $\mathbf{4 4 . 6 A}$ & $\mathbf{4 3 . 2 8 B}$ & $\mathbf{4 1 . 0 3 C}$ & $\mathbf{3 9 . 6 9 D}$ & $\mathbf{3 7 . 9 4 E}$ & $\mathbf{3 5 . 7 9 F}$ & \\
\hline
\end{tabular}

LSD value $(\mathrm{p} \leq 0.05)$ for treatments $=0.35$, storage days $=0.42$ and interaction $=0.94$

\section{Total phenolic contents ( $m g$ GAE $100 \mathrm{~g}^{-1}$ )}

The statistically examined data indicated highly significant results in treatments, storage days and their relation. Increase in TPC activity was more distinct in coconut and oil and fomesa wax than control fruits. After 90 days mean total phenolic contents value was 1.11-fold higher in fruits treated with $30 \%$ coconut oil than untreated fruits. The interactive effects of treatments and storage days untreated fruits showed a continuous decrease in TPC from 30-90. Results revealed that fomesa wax treated fruits 
showed maximum (214.35) total phenolic contents after 45 day storage period followed by fruit treated with $30 \%$ coconut oil (214.20), aloe vera extract $60 \%$ (213.9), TBZ (213.8) while minimum (200.70) was observed in untreated fruits. After 45 days and 90 days of storage period $30 \%$ coconut oil treated fruit 1.07 and 1.40-fold higher as compared to control fruit (Table 2).

Table 2. Effects of different coating treatments on TPC ( $m g$ GAE $\left.100 \mathrm{~g}^{-1}\right)$ of 'Kinnow' fruit stored at $5^{\circ} \mathrm{C}$

\begin{tabular}{c|c|c|c|c|c|c|c|c}
\hline \multirow{2}{*}{\begin{tabular}{c} 
Treatments \\
\cline { 2 - 7 }
\end{tabular}} & $\mathbf{0}$ & $\mathbf{1 5}$ & $\mathbf{3 0}$ & $\mathbf{4 5}$ & $\mathbf{6 0}$ & $\mathbf{7 5}$ & $\mathbf{9 0}$ & Mean \\
\hline $\begin{array}{c}\text { Control } \\
\text { Fomesa Wax }\end{array}$ & $213.50 \mathrm{def}$ & $211.93 \mathrm{ghi}$ & $206.90 \mathrm{l}$ & $200.70 \mathrm{~m}$ & $189.35 \mathrm{n}$ & $171.55 \mathrm{o}$ & $150.18 \mathrm{p}$ & $\mathbf{1 9 2 . 0 1 C}$ \\
$\begin{array}{c}\mathbf{3 0 \%} \text { Coconut } \\
\text { oil }\end{array}$ \\
$\begin{array}{c}\text { 60\% Aloe } \\
\text { Vera } \\
\text { TBZ }\end{array}$ & $213.50 \mathrm{def}$ & $214.90 \mathrm{abc}$ & $215.83 \mathrm{a}$ & $214.35 \mathrm{bcd}$ & $212.80 \mathrm{efg}$ & $211.60 \mathrm{hi}$ & $210.20 \mathrm{~J}$ & $\mathbf{2 1 3 . 3 1 A}$ \\
\hline Mean & $213.50 \mathrm{def}$ & $213.83 \mathrm{cde}$ & $214.35 \mathrm{bcd}$ & $213.90 \mathrm{bcde}$ & $211.20 \mathrm{ij}$ & $210.23 \mathrm{j}$ & $208.70 \mathrm{k}$ & $\mathbf{2 1 2 . 2 4 B}$ \\
\hline
\end{tabular}

$\operatorname{LSD}(p \leq 0.05)$ treatment $=0.43$, storage days $=0.51$ and interaction $=1.14$

\section{Total antioxidants (\%)}

The statistically analyzed data indicated highly significant results. Postharvest application fomesa wax and 30\% coconut oil enhanced (1.20 and 1.19-fold) higher antioxidant activity in contrast to untreated fruits respectively with entire storage period (Table 3).

Table 3. Effects of different coating treatments on total antioxidants (\%) of Kinnow fruit stored at $5^{\circ} \mathrm{C}$

\begin{tabular}{c|c|c|c|c|c|c|c|c}
\hline \multirow{2}{*}{\begin{tabular}{c} 
Treatments \\
\cline { 2 - 8 }
\end{tabular}} & $\mathbf{0}$ & $\mathbf{1 5}$ & $\mathbf{3 0}$ & $\mathbf{4 5}$ & $\mathbf{6 0}$ & $\mathbf{7 5}$ & $\mathbf{9 0}$ & Mean \\
\hline Control & $77.60 \mathrm{bc}$ & $75.50 \mathrm{def}$ & $71.63 \mathrm{jk}$ & $65.67 \mathrm{o}$ & $60.70 \mathrm{p}$ & $50.64 \mathrm{q}$ & $39.75 \mathrm{r}$ & $\mathbf{6 3 . 0 7 C}$ \\
$\begin{array}{c}\text { Fomesa Wax } \\
\mathbf{3 0 \%} \text { coconut } \\
\text { oil }\end{array}$ & $77.60 \mathrm{bc}$ & $78.50 \mathrm{ab}$ & $79.50 \mathrm{a}$ & $75.90 \mathrm{def}$ & $74.55 \mathrm{fgh}$ & $71.63 \mathrm{jk}$ & $70.92 \mathrm{klm}$ & $\mathbf{7 5 . 5 1 A}$ \\
$\begin{array}{c}\mathbf{6 0 \%} \text { aloe vera } \\
\text { extract } \\
\text { TBZ }\end{array}$ & $77.60 \mathrm{bc}$ & $78.24 \mathrm{ab}$ & $79.00 \mathrm{ab}$ & $76.50 \mathrm{~cd}$ & $73.50 \mathrm{hi}$ & $71.58 \mathrm{jkl}$ & $70.00 \mathrm{~m}$ & $\mathbf{7 5 . 2 0 A}$ \\
\hline & $77.60 \mathrm{bc}$ & $76.00 \mathrm{de}$ & $77.85 \mathrm{bc}$ & $75.00 \mathrm{efg}$ & $73.20 \mathrm{hi}$ & $72.78 \mathrm{ij}$ & $67.55 \mathrm{n}$ & $\mathbf{7 4 . 2 8 B}$ \\
\hline Mean & $\mathbf{7 7 . 6 0 A}$ & $\mathbf{7 7 . 2 7 A}$ & $\mathbf{7 7 . 1 8 A}$ & $\mathbf{7 3 . 6 5 B}$ & $\mathbf{7 1 . 1 9 C}$ & $\mathbf{6 7 . 3 6 D}$ & $\mathbf{6 3 . 2 9 E}$ & \\
\hline
\end{tabular}

LSD value $(\mathrm{p} \leq 0.05)$ for treatments $=0.54$, storage days $=0.64$ and interaction $=1.43$

$30 \%$ coconut oil treated fruits showed 1.10, 1.21 and 1.76-fold higher after 30, 45 and 90 days of cold storage than untreated fruits. Interaction showed that highest antioxidant activity (70.92) was observed in fomesa wax followed by the treatment of $30 \%$ coconut oil $(70.0), 60 \%$ aloe vera extract $(68.25 \%)$, TBZ (67.55) and control 
treatment $(39.75 \%)$ respectively after 90 day storage period. $30 \%$ coconut oil and and commercial wax showed parallel results in stored fruits. The interactive effects revealed that antioxidant potential of fruit increased up to 0-30 days but reduced gradually up to 90 days. Moreover; $30 \%$ coconut oil was more useful to maintain antioxidant activities for long time period (Table 3).

\section{Catalase ( $U \mathrm{mg}^{-1}$ protein)}

The data pertaining to CAT enzyme activity of Kinnow fruits illustrated statistically significant outcomes in treatments, storage days and their interactions. The control treatment exhibited the lowest catalase activity as compared to the Kinnow fruit treated with fomesa wax and 30\% coconut oil having highest (1.31 and 1.30-fold) catalase activity respectively during storage. Interaction of treatment and storage time revealed falling trend in catalase enzyme activity with prolonged storage but also reduced after 30-60 days depending on treatments. Maximum catalase activity (18.70) was observed in fomesa wax treated fruits followed by treatments of $30 \%$ coconut oil (18.10), aloe vera extract 60\% (17.23), TBZ (17.0) and control treatment (9.03) respectively after 90 days of storage period. Kinnow fruits treated with fomesa wax showed increase up to 45 days however $30 \%$ coconut oil also performed at par to maintain catalase activity on the other hand control treatment initially start decline (Figure 7).

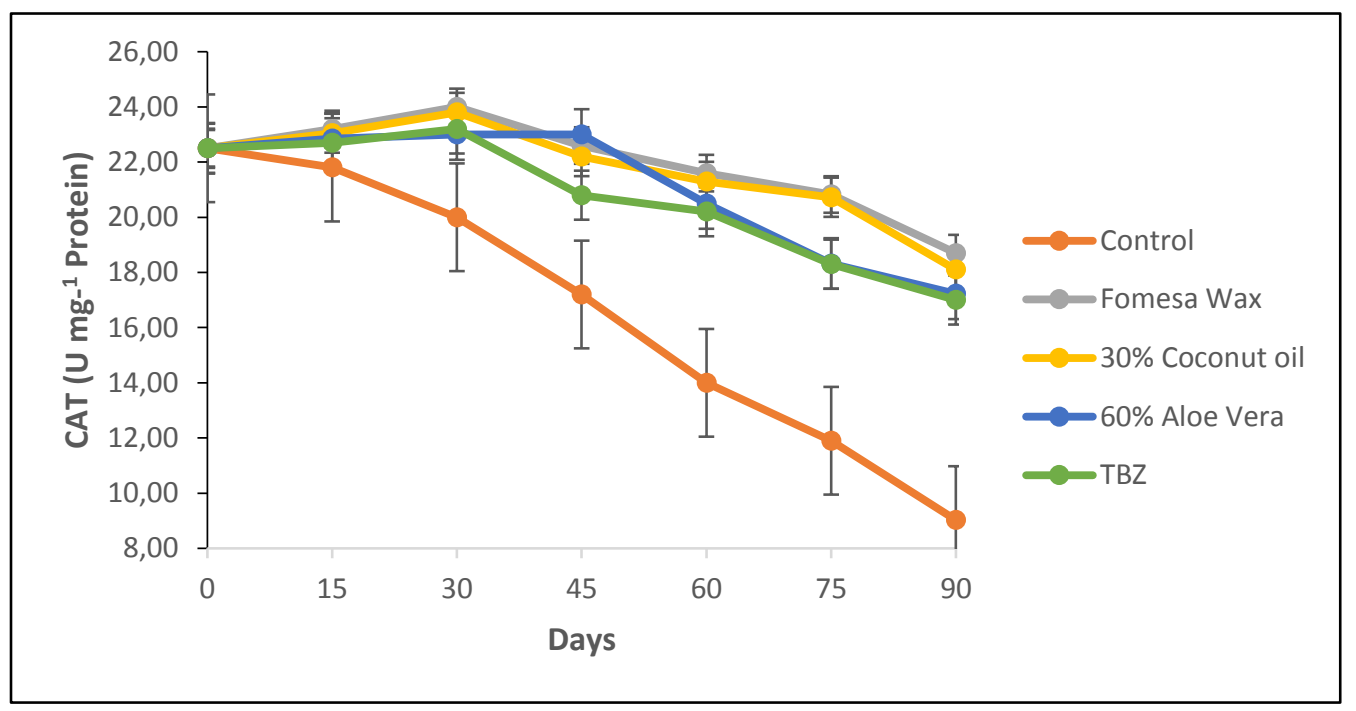

Figure 7. Effects of different coating treatments on catalase $\left(\mathrm{U} \mathrm{mg}^{-1}\right.$ protein) of Kinnow fruit stored at $5^{\circ} C . L S D$ value $(p \leq 0.05)$ for treatments $=0.27$, storage days $=0.31$ and interaction $=0.71$

\section{Peroxidase ( $U \mathrm{mg}^{-1}$ protein)}

The data regarding to POD enzyme activity of Kinnow fruits illustrated statistically non-significant results but their interactions for treatments and storage days was significant. The highest peroxidase enzyme activity (1.16-fold) was observed and Kinnow treated with fomesa wax and 30\% coconut oil having highest (21.92) peroxidase enzyme activity followed by fruit treated with $30 \%$ coconut oil as compared to untreated fruit during storage. $30 \%$ coconut oil treated fruit showed 1.18, 1.23 and 1.46-fold higher POD enzyme activity after 45, 60 and 90 days of storage than control fruits (Figure 8). 


\section{Superoxide dismutase $\left(U \mathrm{mg}^{-1}\right.$ protein)}

The data related to SOD enzyme activity of Kinnow fruits demonstrated significant outcomes in treatments, storage time and their relation. The activity of SOD enzyme was increased to its peak when fruit treated with coconut oil than control fruit during entire storage. The Kinnow fruits dipped in fomesa wax and $30 \%$ coconut oil exhibited 1.08 and 1.07-fold higher SOD activity than untreated fruit during cold storage. It was noted that higher SOD enzyme activity was observed in fomesa wax treated fruits (1.15fold) and 30\% coconut oil (1.14-fold) as compared to untreated fruit after 90 days. High value of SOD activity (117.50) was observed in fomesa wax treated fruits after 15 days of storage period. $30 \%$ coconut oil and fomesa wax indicated almost at par to maintain SOD activity during storage (Figure 9).

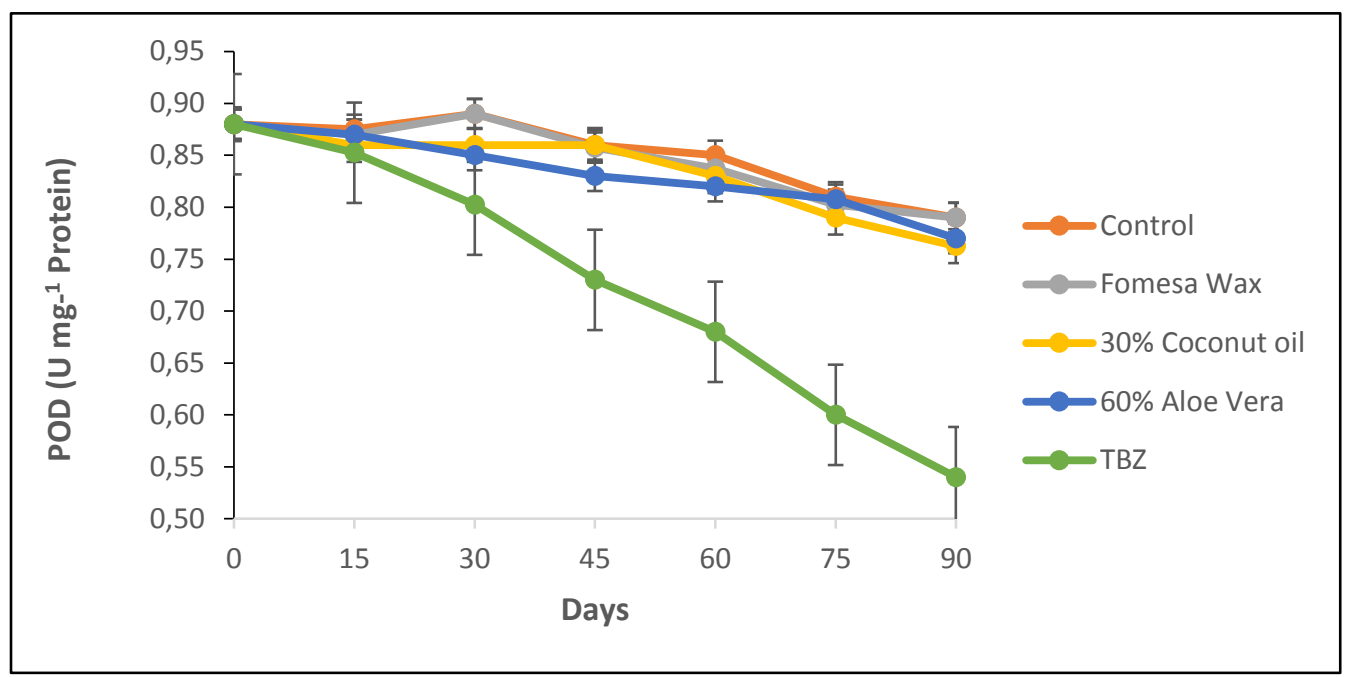

Figure 8. Effects of different coating treatments on peroxidase ( $\mathrm{mg}^{-1}$ protein) of Kinnow stored at $5^{\circ} C . L S D$ value $(p \leq 0.05)$ for treatments $=0.01$, storage days $=0.02$ and interaction $=0.04$

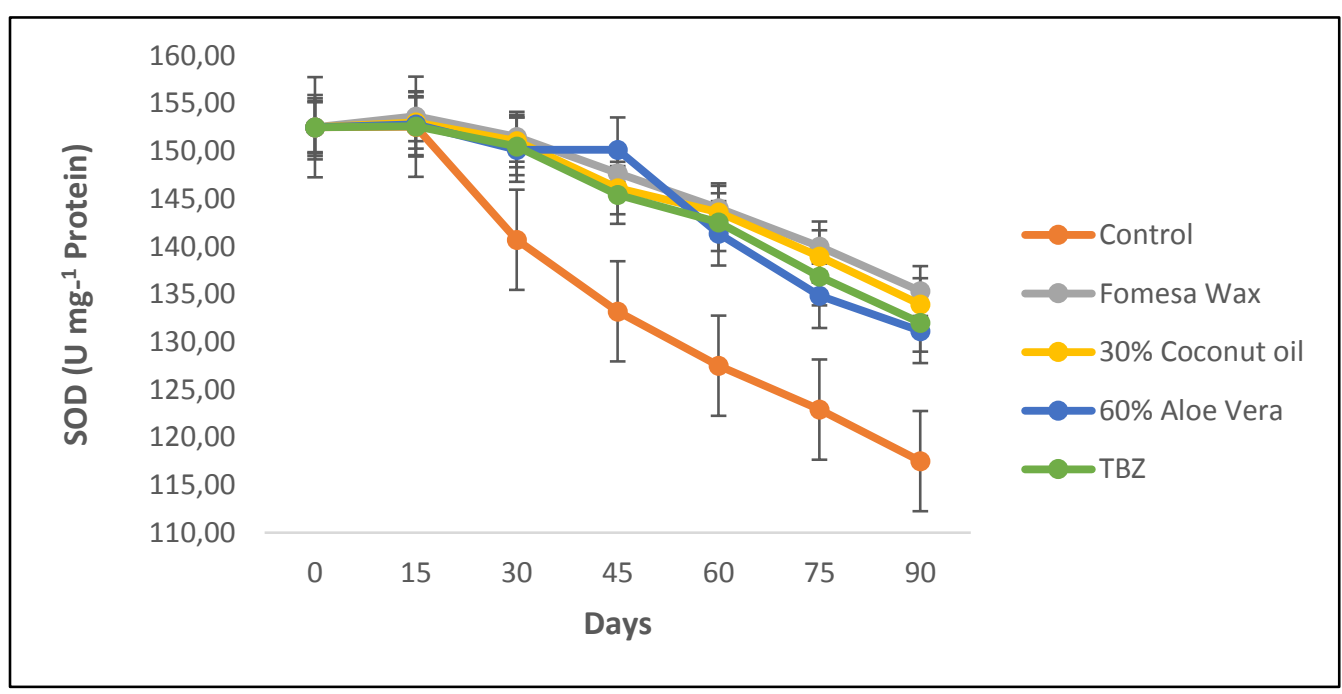

Figure 9. Effects of different coating treatments on superoxide dismutase ( $U \mathrm{mg}^{-1}$ protein) of Kinnow fruit stored at $5^{\circ} C . L S D$ value $(p \leq 0.05)$ for treatments $=0.64$, storage days $=0.75$ and interaction $=1.68$ 


\section{Discussion}

It is quite obvious from the results of the study that among all the treatment applied to Kinnow mandarin for the extension of storage life $30 \%$ coconut oil proved to be the best during 90 days of the storage. This is clear as fruit is living entity after the harvest and various physiological processes especially the respiration and transpiration are going on which utilizes the substrate present in the fruit so the fruit losses its weight because of these processes. Similar results of increasing physiological loss in weight during storage has also been reported in Grapes (Shiri et al., 2011), Jujube fruits (Xing et al., 2015; Shahi et al., 2015), and Mango (Carrillo et al., 2000; Gill et al., 2015). The results of current study for weight loss was in similar with the findings of Albanese et al. (2007) who explained that coating treatment slow down the weight loss. The coated fruits showed a positive action of prestorage treatment which slow down transpiration, because these coatings create a layer on citrus fruit surface that inhibit the evaporation. Likewise, in another study conducted by Krasniewska et al. (2014) it was found that the coatings of pullulan on apple and pepper decreased the weight loss in these fruits.

Coatings of fomesa wax and $30 \%$ coconut oil inhibited the agents of moisture particularly and due to this minimum decay loss happened. Yadav et al. (2010) described the reason of decay loss which was due to wax coating's interaction effect as moisture inhibitor as well as microbial inhibitor in their point of view. Similar results were found in Asian pear when observed by Mahajan et al. (2013). On the other hand, Gautam et al. (2003) reported the same results in mango, Ahmad et al. (2005) and Yadav et al. (2010) in Kinnow mandarin reported minimum decay loss during the period of storage by applying wax on these fruits.

Results concerning about TSS in this research showed that fruits treated with $30 \%$ coconut oil had lower total soluble solids as comparing them to control treatment. Increased TSS in control was due to solute accumulated in vacuoles of cells and starch gets hydrolyzed in to sugars. The increase in TSS up to 15 days may be attributed due to the hydrolysis of acid and deposition of polysaccharide as reported earlier by Omayma et al. (2010). Probable reason in reduction of TSS in 30\% coconut oil treated fruit was due to the conversion of polysaccharides in to disaccharides and monosaccharaides means less hydrolysis of starch into sugars.

The higher titratable acidity in the commercial wax (fomesa wax) and $30 \%$ coconut oil treated Kinnow fruits could be because of least consumption of acids in the process of respiration during storage. The decrease in acidity in control treatment was probably due to the utilization of citric acid by the microbes as a source of carbon and $\mathrm{O}_{2}$ collected inside caused acidosis after dissolving and developing carbonic acid (Carrillo et al., 1995). The coatings facilitated in better maintenance of titratable acidity than control fruits, which could be because of the positive role of coatings in delaying the process of ripening in fruits (El-Anany et al., 2009). Patriaca et al. (2005) indicated that coatings were effective in retention the titratable acidity of Kinnow.

Generally, vitamin C contents of fruits decreasing during storage. However, the $30 \%$ coconut oil and fomesa wax treated fruits showed higher contents of vitamin $\mathrm{C}$ as compared to control after 90 days storage. During the period of storage, the ascorbic acid was degraded which decreased the vitamin C. Similarly, Lee and Kader (2000) proposed that leaching in thermal breakdown and surrounding water became the reason of vitamin C loss. There were similar results shown by Sonkar et al. (2009) in Kinnow, Ahmad et al. (2005) in Kinnow, Deka et al. (2006) in mandarin. These studies indicated that there were maximum contents of Vitamin $\mathrm{C}$ in the fruits which were coated with 
wax. Dehydro ascorbic acid is formulated as a result of moderate oxidation of vitamin $\mathrm{C}$, as it is a fact that vitamin $\mathrm{C}$ is quite vulnerable to oxidative deterioration.

Shahid and Abbasi (2011) reported that there was maximum vitamin $C$ in fresh fruit before ripening and after that due to the ascorbic acid oxidase action it was decreased. Generally, a major part of ascorbic acid transformed into juice and oxidized. The present study indicated that fruits treated with $30 \%$ coconut oil showed similar results as commercial wax had higher total phenolic contents of the Kinnow fruits in contrast to untreated fruits.

Paolo and Marisol (2008) in their research revealed that during storage, the total phenolic contents increased and vitamin $\mathrm{C}$ reduced. Consequently, phenolic compounds synthesis becomes the reason of increase in antioxidant activity during the period of storage of Kinnow fruit. They reported the reduction in phenol content of control and Kinnow coated with herbal extract, essential oil and commercial wax during the period of storage, these findings are a sequence of the results of Lim et al. (2006) who conducted research on fruit of citrus. During the period of storage, polyphenol oxidase enzymes' oxidative activity is related with the decrease in total phenols contents which makes the phenol to quinones compound. During the initial days, a sudden increase in the phenolic contents was observed it is due to the fact that due to reduction in temperature activation and generation of certain phenolic contents happened, as a result of above phenomenon dehydration of Kinnow occurred which further increased the juice phenolics (Silva et al., 2013). After a definite time period the phenolics decreased because antioxidant activity decrease which is sign of minimum resistance of fruits against the attack of pathogen.

The increase in activity of antioxidant enzymatic at early stages may because of environmental stress which increases the ROS level at protein, which finally modifies the cellular homeostasis (Suzuki and Mittler, 2006). Antioxidant activity's foresaid results demonstrated that Kinnow fruit which was coated with the wax and coconut oil with $30 \%$ encourage the scavenging capacity. Fruits of coated Kinnow which were stored at temperature of $4^{\circ} \mathrm{C}$ showed reduction in antioxidant activity after 90 days because of rigorous reduction in phenolics and ascorbic acid through biosynthesis. Hassanpour et al. (2015) reported the dependency of antioxidant activity upon flavonoids, anthocyanins, total phenols and ascorbic acid. They also supported the current results on antioxidant activity.

\section{Conclusion}

It was concluded that $30 \%$ coconut oil performed best among all the treatments. The fruits treated with $30 \%$ coconut oil showed minimum weight loss, fruit rot, maximum juice weight, biochemical parameters like total soluble solids, titratable acidity, ascorbic acid contents, total sugar, maximum total antioxidants and maximum enzymatic activity (CAT, POD and SOD) of Kinnow mandarin fruits which were stored up to 90 days. It was also evaluated that $60 \%$ aloe vera extract proved valuable for long term storage of Kinnow mandarin and to control the storage rot because it performed almost at par to commercial fungicide. Hence botanical extracts can improve the storage life of Kinnow mandarin so it can be recommended to overcome the storage issues of Kinnow fruits. Finally, it was obvious from experiment that prestorage treatment of $30 \%$ coconut oil was most effective to reduce decay losses and maintain the fruit quality during 90 days storage. 


$$
-727 \text { - }
$$

\section{Future recommendations}

There is a need to explore the penetration level of these treatments molecular level studies are also required to check the efficacy and accuracy. Effects of these prestorage applications on bio profile of phenolics and antioxidants, flavonoids should be checked to find a best treatment in terms of international standards.

\section{REFERENCES}

[1] Ahmad, M. S., Thakur, K. S., Kaushal, B. B. L. (2005): Post-Harvest Treatments to Reduce Postharvest Losses in Kinnow Mandarin. - Indian J. Hortic. 62: 63-67.

[2] Ainsworth, E. A., Gillespie, K. M. (2007): Estimation of total phenolic contents and other oxidation substances in plant tissue using Folin-Ciocalteu reagent. - Nature Protocols 2: 875-877.

[3] Albanese, D., Cinquanta, L., Di Matteo, M. (2007): Effects of an innovative dipping treatment on the cold storage of minimally processed Annurca apples. - Food Chem.105: 1054-1060.

[4] AOAC. (2000): Official methods of analysis of Association of Official Analytical Chemists, $16^{\text {th }}$ ed. - Association of Official Analytical Chemists, Arlington, VA.

[5] Arowora, K. A., Williams, J. O., Adetunji, C. O., Fawole, O. B., Afolayan, S. S., Olaleye, O. O., Adetunji, J. B., Ogundele, B. A. (2013): Effects of Aloe vera Coatings on Quality Characteristics of Oranges Stored under Cold Storage. - Greener J. Agric. Sci. 3(1): 3947.

[6] Bisen, A., Pandey, S. K. (2008): Effect of postharvest treatments on biochemical and organoleptic constitutes of Kazgi lime fuits during storage. - J. Hort. Sci. 3: 53-56.

[7] Biswas, K. I., Chattopadhyay, I., Benerjee, R. K., Bandyopadhyay, U. (2002): Biological activities and medical properties of neem (Azadirachta indica). - Current Sci. 82: 701711.

[8] Carrillo, L. A., Ramirez-Bustamante, M. F., Valdez-Torres, J. B., Rojas-Villegas, R., Yahia, E. M (2000): Ripening and quality changes in Mango fruit as affected by coating with an edible film. - J. Food Qual. 23: 479-486.

[9] Castillo, S., Navarro, D., Zapata, P. J., Guillen, F., Valero, D., Serrano, M., Martinez, R. D. (2010): Antifungal decacy of Aloe vera in vitro and its use as a preharvest treatment to maintain postharvest table grape quality. - J. Postharvest Bio. Tech. 57: 183-188.

[10] Chauhan, S. H., Gupta, K. C., Agrawal, M. (2014): Application of biodegradable Aloe vera gel to control postharvest decay and longer the shelf life of grapes. - Int. J. Current Microbiol. Appl. Sci. 3: 632-642.

[11] Creel, R. E. (2006): Effect of acacia gum on postharvest quality of cut flowers. - Master of Science Thesis. Auburn, Alabama University. Pp.70.

[12] Deka, B. C., Sharma, S., Borah, S. C. (2006): Postharvest management practices for shelf life extension of khasi mandarin. - Indian J. Horti. 63: 251-255.

[13] El-Anany, A. M., Hasssan, G. F. A., Ali, F. M. R. (2009): Effects of edible coatings on the shelf life and quality of apple during cold storage. - J. Food Technol. 7: 5-11.

[14] Fan, Y., Xu, Y., Wang, D., Zhang, L., Sun, J., Sun, L. (2009): Effect of alginate coating combined with yeast antagonist on strawberry (Fragaria $\times$ ananassa) preservation quality. Postharvest Biol. Technol. 53: 84-90.

[15] FAO. (2006): The impact of postharvest handling losses, sugar and beverage group raw materials, tropical and horticulture products service commodities and trade division. Food Agri. Org. United Nations.

[16] FAOSTAT. (2017): Food and Agricultural Organization of United Nations. - Available online with updates at http:/www.faostat.fao.org/site/342/default.aspx. 
[17] Garcia, M. A., Marisabel, V., Diaz, R., Falco, S., Asariego, A. C. (2013): Effects of Aloe vera coating on postharvest quality of tomato Fruits. - J. Food Sci. 69: 117-126.

[18] Gautam, B., Sarkar, S. K. Reddy, Y. N. (2003): Effect of post-harvest treatments on shelf life and quality of Banganapalli Mango. - Ind. J. Hortic. 60: 135-139.

[19] Gill, P. P. S., Jawandha, S. K., Kaur, N., Singh, N., Sangwan, A. (2015): Effect of LDPE packaging on post-harvest quality of Mango fruits during low temperature storage. - The Bioscan. 10: 177-180.

[20] GOP, Government of Pakistan. (2015): Pakistan Statistical Year Book. - Federal Bureau of Statistics, Statistic Division of Pakistan.

[21] Grainge, M. S., Ahmed, W. C., Mitchel, L., Hylen, W. (1984): Plant species reportedly possessing pest control properties, an EWC/UN data base. - Resource system institute EWC Honoly College of Tropical Agriculture and Human Resource, UWV of Hawaii.

[22] Hassanpour, H. (2015): Effect of Aloe vera gel coating on antioxidant capacity, antioxidant enzyme activities and decay in raspberry fruit. - J. Food Sci. Technol. 60: 495-501.

[23] Khalid, M. S., Malik, A. U., Sleem, B. A., Khan, A. S., Javed, N. (2012): Horticultural mineral oil application and tree canopy management improve cosmetic fruit quality of Kinnow mandarin. - African J. Agri. Res. 7: 3464-3472.

[24] Krasniewska, K., Gniewosz, M., Synowiec, A., Przybyl, J. L., Baczek, K., Weglarz, Z. (2014): The use of pullulan coating enriched with plant extracts from Satureja hortensis L. to maintain pepper and apple quality and safety. - Postharvest Biol. Technol. 90: 6372.

[25] Lim, Y. Y., Lim, T. T., Tee, J. J. (2006): Antioxidnat properties of Guava fruit; comparison with some local fruit. - Suway. Acad. J. 3: 9-20.

[26] Mahajan, B. V. C., Dhillon, W. S., Kumar, M. (2013): Effect of surface coatings on the shelf life and quality of Kinnow fruits during storage. - J. Postharvest Technol. 1: 8-15.

[27] Nidiry, E., Ganeshan, G., Lokesha, A. (2011): Antifungal activity of some extractives and constituents of aloe vera. - Res. J. of Medicinal Plant. 5: 196-200.

[28] Obenland, D., Collin, S., Sievert, J., Fjeld, K., Doctor, J., Arpaia, M. L. (2008): Commercial packing and storage of navel oranges alters aroma volatiles and reduces flavor quality. - Postharvest Biol. Technol. 47: 159-167.

[29] Omayma, M. I., Eman, A. A. E., Abd-Allah, A. S. E., El-Naggar, M. A. A. (2010): Influence of some post-harvest treatments on guava fruits. - Agric. Biol. J. N. Am. 1: 1309-1318.

[30] Paolo, R., Marisol, L. B. (2008): Effect of cold storage on vitamin C, phenolic and antioxidant activity of five orange genotypes (Citrus sinensis (L.) Osbeck). - Postharvest Biol. Technol. 49: 348-354.

[31] Patriaca, S., Palmu, T., Grosso, C. R. F. (2005): Effect of edible wheat gluten based films and coatings on refrigerated strawberry quality. - Postharvest Biol. Technol. 36: 199-208.

[32] Pesticide Action Network. (2012): Pesticide residues in food. Pest management notes No. 8. - Available at: http://www.pan-uk.org/archive/Internet/IPMinDC/pmn8.pdf.Date of Retreival: 06 August, 2012.

[33] Romanazzi, G. (2010): Chitosan treatment for the control of postharvest decay of table grapes, strawberries and sweet cherries. - Global science Books 10: 111-114.

[34] Serrano, M., Castillo, S., Valverde, J., Martianez-Romero, D., Guillean, F., Valero, D. (2006): Use of Aloe vera gel coating preserves the functional properties of table grapes. J. Agri. Food Chem. 54: 3882-3886.

[35] Shahi, M., Rastegar, S., Khankahdani, H. H. (2015): Effects of essential oil and calcium chloride on quantitative and qualitative features Ziziphus mauritiana during storage. - Int. J. Plant. Ani. Sci. 5: 25-31.

[36] Shiri, M. A., Ghasemnezha, D., Bakhshi, D., Dadi, M. (2011): Changes in phenolic compounds and antioxidant capacity of fresh-cut table grape (Vitis vinifera) cultivar 
'Shahaneh' as influence by fruit preparation methods and packagings. - Aus. J. Crop Sci. 5: 1515-1520.

[37] Siddique, M. I., Garnevska, E. (2018): Citrus Value Chain (s). - A Survey of Pakistan Citrus Industry.

[38] Sindhu, S. S., Singhrot, R. S. (2016): Effect of oil emulsion and chemicals on shelf life of baramasi lemon. - Haryana J. Hort. 25: 67-73.

[39] Singh, D., Thakur, R. K., Singh, D. (2018): Effect of pre harvest sprays of fungicides and calcium nitrate on post-harvest rot of Kinnow in low storage. - Plant Dis. Res. 18: 9-11.

[40] Sogvar, O. M., Saba, M. K., Emamifar, A. (2016): Aloe vera and ascorbic acid coatings maintain postharvest quality and reduce microbial load of strawberry fruit. - Postharvest Biol. Technol. 114: 29-35.

[41] Sonkar, R. K., Sarnaik, D. A., Dikshit, S. N., Saxena, R. R. (2009): Individual Stretch Film Wrapped Kinnow Mandarin under Ambient Storage. - Ind. J. Hortic. 66: 22-27.

[42] Steel, R. G. D., Torrie, J. H., Dicky, D. A. (1997): Principles and Procedures of Statistics: A Biological Approach. 3rd ed. - McGraw Hill Book Co. Inc., New York, USA.

[43] Suzuki, N., Mittler, R. (2006): Reactive oxygen species and temperature stresses: A delicate balance between signaling and destruction. - Physiol. Plant. 126: 45-51.

[44] TDAP. (2018): Exports from Pakistan July-December, 2017-18 (Provisional). - Available online with Updates on http://www.tdap.gov.pk/tdap-statistics.php.

[45] Tietel, Z., Bar, E., Lewinsohn, E., Feldmesser, E., Fallik, E., Porat, R. (2010): Effects of wax coatings and postharvest storage on sensory quality and aroma volatile composition of 'Mor' mandarins. - J. Sci. Food Agric. 90: 995-1007.

[46] Valverde, J., Valero, D., Martinez-Romero, D., Guillen, F., Castillo, S., Serrano, M. (2005): Novel edible coating based of Aloe vera gel to maintain table grape quality and safety. - Agric Food Chem 53(20): 7807-13.

[47] Xing, Y., Lin, H., Cao, D., Xu, Q., Han, W., Wang, R., Che, Z., Li, X. (2015): Effect of chitosan coating with cinnamon oil on the quality and physiological attributes of China jujube fruits. - Biomed. Res. Int. 15: 1-10.

[48] Xu, W. T., Huang, K. L., Guo, F., Qu, W., Yang, J. J. (2007): Postharvest grapefruit seed extract and chitosan treatment of table grapes to control Botrytis cinerea. - Postharvest Biol. Technol. 46: 86-94.

[49] Yadav, M., Kumar, N., Singh, D. B., Singh, G. K. (2010): Effect of postharvest treatments on shelf life and quality of Kinnow mandarin. - Ind. J. Hortic. 67: 243-248. 